\title{
Investigation of the Larvicidal Potential of Silver Nanoparticles against Culex quinquefasciatus: A Case of a Ubiquitous Weed as a Useful Bioresource
}

\author{
Elijah T. Adesuji, ${ }^{1}$ Omolara O. Oluwaniyi, ${ }^{2}$ Haleemat I. Adegoke, ${ }^{3}$ Roshila Moodley, \\ Ayomide H. Labulo, ${ }^{1,4}$ Olusola S. Bodede, ${ }^{4}$ and Charles O. Oseghale ${ }^{1}$ \\ ${ }^{1}$ Department of Chemistry, Federal University Lafia, PMB 146, Lafia, Nigeria \\ ${ }^{2}$ Department of Industrial Chemistry, University of Ilorin, Ilorin, Nigeria \\ ${ }^{3}$ Department of Chemistry, University of Ilorin, Ilorin, Nigeria \\ ${ }^{4}$ School of Chemistry, University of KwaZulu-Natal, Westville Campus, Durban, South Africa \\ Correspondence should be addressed to Elijah T. Adesuji; turpsyelikay20@yahoo.com
}

Received 24 November 2015; Revised 26 February 2016; Accepted 1 March 2016

Academic Editor: Yogendra Mishra

Copyright (C) 2016 Elijah T. Adesuji et al. This is an open access article distributed under the Creative Commons Attribution License, which permits unrestricted use, distribution, and reproduction in any medium, provided the original work is properly cited.

\begin{abstract}
Biosynthesized silver nanoparticles (AgNPs) using Cassia hirsuta aqueous leaf extract were reported in this study. The synthesis was optimized by measuring various parameters such as temperature, time, volume ratio, and concentration. The surface plasmon resonance at $440 \mathrm{~nm}$ for $30^{\circ} \mathrm{C}$ and $420 \mathrm{~nm}$ for both $50^{\circ} \mathrm{C}$ and $70^{\circ} \mathrm{C}$ measured using the UV-Vis spectrophotometer confirmed the formation of AgNPs synthesized using C. hirsuta (CAgNPs). The functional groups responsible for the reduction and stabilization of the NPs were identified using Fourier Transform Infrared (FTIR). The morphology, size, and elemental composition of the NPs were obtained using scanning electron microscope (SEM), transmission electron microscope (TEM), and energy dispersive X-ray spectroscopy (EDX). X-ray diffractometer was used to identify the phases and crystallinity of CAgNPs. Crystalline spherical NPs with average diameter of $6.9 \pm 0.1 \mathrm{~nm}$ were successfully synthesized. The thermal analysis of CAgNPs was observed from DSC-TGA. The larvicidal results against the different larva instar stage of Culex quinquefasciatus gave $\mathrm{LC}_{50}=4.43 \mathrm{ppm}$ and $\mathrm{LC}_{90}=8.37 \mathrm{ppm}$. This is the first study on the synthesis of AgNPs using C. hirsuta and its application against lymphatic filariasis vector. Hence, it is suggested that the C. hirsuta synthesized AgNPs would be environmentally benign in biological control of mosquito.
\end{abstract}

\section{Introduction}

Mosquitoes are a well-known group of insects widely distributed worldwide. They are important vectors which transmit many dreadful diseases such as malaria, yellow fever, filariasis, dengue, and haemorrhagic fever. More than 500 million people are infected annually. In Nigeria, mosquitoborne diseases constitute a major health problem. It is statistically shown that malaria alone accounts for about 300000 deaths from over 20 million clinical cases annually, while other mosquito-borne diseases have accounted for a lot of economic loss, social disgrace, low productivity, absenteeism, and sleeplessness [1]. Culex species usually breed profusely in polluted gutters, blocked drains, and other water retention habitats containing organic matter unlike Aedes and Anopheles mosquitoes which prefer clean ground pools and man-made containers, respectively [2]. Culex quinquefasciatus is a vector of lymphatic filariasis, which affects 120 million people worldwide, and approximately 400 million people are at risk of contracting filariasis, resulting in an annual economic loss of US\$1.5 billion [3]. Culex quinquefasciatus accounts for over $70 \%$ of the mosquitoes in Nigeria. Filariasis has been shown to be a public health problem in Africa, particularly in the northern savannah and in the south-western coastal parts of Africa [4]. Infection with lymphatic filariasis, commonly known as elephantiasis, occurs when threadlike, filarial parasites are transmitted to humans through mosquitoes [5]. Larviciding is the application of chemicals 
to kill mosquito larvae or pupae in the water. It is generally more effective and target-specific than applying chemicals to kill adult mosquitoes (adulticiding). In controlling mosquitoes' larvae, dichlorodiphenyltrichloroethane (DDT), organophosphate temephos, methoprene, pyrethroids, phytochemicals, and soil bacterium (Bacillus thuringiensis israelensis and Bacillus sphaericus) have been employed [6]. These insecticides have been reported to pose serious threats to the environment in killing nontarget species such as larval predators, bioaccumulation, hampering biodiversity, and environmental pollution [7]. Continuous application of these insecticides results in control failures, incidences of resistance, and disease resurgence owing mainly to the development of resistance in the vectors [8].

Plants contain an untapped reservoir of phytochemicals that can be used directly or as templates for synthetic pesticides. Phytochemicals have been reported to have larvicidal, pupicidal, and adulticidal activities, most being repellants, ovipositional deterrents, and antifeedants against both agricultural pests and medically important insect species [9]. Plant extracts and essential oils obtained from various plants have demonstrated promising larvicidal activities against mosquito vectors [10].

A nanoparticle is the most fundamental component in the fabrication of a nanostructure. Nanometer-sized metallic particles show unique and considerably changed physical, chemical, and biological properties compared to their macroscaled counterparts, due to their high surface-tovolume ratio [11] and various methods of making nanoparticles using plant extracts have been reported [12]. Silver nanoparticles (AgNPs) have important applications due to their very small size and large surface-to-volume ratio. They have found useful applications in various aspects of human life. Preparation of AgNPs using biological methods is constantly being exploited. Biosynthesis of AgNPs using extracts of neem (Azadirachta indica) [13], Citrus limon [14, 17], pineapple leaf [15], Thevetia peruviana [16], Piper nigrum [18], and Ocimum sanctum [19] has been reported. Also different matrices have been used in synthesizing AgNPs $[20,21]$. Recently, our group studied the growth processes and kinetics of AgNPs synthesized using diverse plants [22].

Different researchers have reported the larvicidal activity of AgNPs synthesized using different plant extracts such as Beauveria bassiana [23], Isaria fumosorosea (Ifr) [24], Sida acuta [6], Leucas aspera [25], Feronia elephantum [26], Azadirachta indica (Neem) [27], Morinda tinctoria [28], Agave sisalana [29], Eclipta prostrata [30], Ficus racemosa [31], Parthenium hysterophorus [32], Pithecellobium dulce [33], Couroupita guianensis [34], Delphinium denudatum [35], Agaricus bisporus [36], Solanum nigrum L. [37], Cocos nucifera coir [38] and Sterculia foetida L. [39] against different stages of larvae of Culex quinquefasciatus, Anopheles stephensi, and Aedes aegypti.

Cassia hirsuta (stinking Cassia) belongs to the family Caesalpiniaceae. It is a woody annual herb or undershrub herb native to Africa [40]. The plant grows as a weed in field crops, waste places, roadsides, and bush regrowths. Different parts of this plant have been used for stomach ache, dysentery, abscesses, rheumatism, hematuria, fever, and other diseases. The seed of $C$. hirsuta contains a water-soluble gum, though not in commercial quantities, and it also contains bioanthraquinone which may prove medicinally important [41]. The petals of $C$. hirsuta were reported to contain cardiac glycosides [41] while the presence of tannins [42], phlobatannins [43], alkaloids, glycosides, anthraquinone glycosides, steroids, and flavonoids has been reported in the leaf extract [44]. The antioxidant, antibacterial, and cytotoxic activities of C. hirsuta leaf extract have been investigated [45] and high quantities of carbohydrate and proteins have been reported [43]. However, there have been no reports on the biosynthesis of AgNPs using C. hirsuta. The present study therefore aims at biosynthesizing AgNPs using C. hirsuta aqueous leaf extract and applying the synthesized nanoparticles in the control of Culex quinquefasciatus.

\section{Materials and Methods}

2.1. Collection of Plant Material. Fresh leaves of C. hirsuta were collected from Tanke area, University of Ilorin Road, and the taxonomic identification was done at the Herbarium, Department of Plant Biology, University of Ilorin, Nigeria. A voucher specimen (UIH 001/1135) was housed in the herbarium.

2.2. Collection of Mosquito Larvae. First- and second-instar larvae of Culex quinquefasciatus were collected from stagnant water within Ilorin metropolis, North Central Nigeria, and identified at the Entomology Unit, Department of Zoology, University of Ilorin, Nigeria. The larvae were kept in plastic trays containing tap water. They were maintained and reared in the laboratory to late III or early IV instars with dog biscuits and yeast powder in a $3: 1$ ratio $[6,46]$.

2.3. Preparation of Plant Extracts. The leaves of C. hirsuta were washed thoroughly with double distilled water (DDW) and cut into small pieces. Approximately $5 \mathrm{~g}$ of the leaves was then boiled with $100 \mathrm{~mL}$ of DDW for 10 minutes and filtered through a Whatman number 1 filter paper. The filtrate was then stored at $4^{\circ} \mathrm{C}$ until further use.

2.3.1. Synthesis of Silver Nanoparticles (AgNPs). In a typical reaction procedure, the aqueous extract was added to $1 \mathrm{mM}$ of silver nitrate solution in $1: 4$ volume ratio. The mixture was allowed to incubate at $30^{\circ} \mathrm{C}$ for $30 \mathrm{~min}$. The solution changed to a reddish-brown color, indicating the formation of AgNPs [16].

2.3.2. Optimization of the Reaction Conditions. Temperature, time, volume, and concentration were optimized by measuring the electronic absorption spectra for each condition. Optimum reaction volume was determined by varying the volume ratio of $C$. hirsuta aqueous leaf extract to $\mathrm{AgNO}_{3}$ solution. The optimization of concentration was carried out by varying $\mathrm{AgNO}_{3}$ concentration from 1 to $5 \mathrm{mM}$. Temperature optimization was conducted by incubating the reaction mixture at three different temperatures 30,50 , and $80^{\circ} \mathrm{C}$. 
The reaction was carried out at different intervals $(5,10,15$, 20,30 , and $45 \mathrm{~min}$ ) to determine the optimum time.

2.3.3. Separation and Purification of Silver Nanoparticles (AgNPs). The AgNPs synthesized using C. hirsuta (CAgNPs) were repeatedly centrifuged at $15,000 \mathrm{rpm}$ for ten minutes. The centrifugation was repeated three times. This was done to ensure that any adsorbed substances on the surface of the AgNPs were removed.

2.3.4. Characterization of CAgNPs. The synthesis of CAgNPs was monitored by UV-Vis spectroscopy. The wavelength ranged between 200 and $900 \mathrm{~nm}$ using the T60 UV-Visible spectrophotometer at a resolution of $1 \mathrm{~nm}$. The FTIR spectra of CAgNPs and the leaf extract were recorded using Shimadzu (8400S) Fourier Transform Infrared at a resolution of $4 \mathrm{~cm}^{-1}$ in $\mathrm{KBr}$ pellets.

The crystallinity of the CAgNPs was examined using an $\mathrm{X}$-ray diffractometer with monochromatic $\mathrm{CuK} \alpha$ radiation $(\theta=1.5406 \AA)$ operating at a voltage of $40 \mathrm{kV}$ and a current of $30 \mathrm{~mA}$ at room temperature. The intensity (AU) data for the AgNPs was collected over a $2 \theta$ range of $20^{\circ}-90^{\circ}$. A scanning electron microscope (SEM) equipped with an EDX attachment and a transmission electron microscope (TEM) were used to characterize the nanoparticles surface morphology and measure the size. TEM measurements were performed on a JEOL TEM 1010 transmission electron microscope at $200 \mathrm{kV}$. The TEM images were processed using Image $1.42 \mathrm{q}$ software to obtain the particle size. Carl Zeiss ultraplus field emission scanning electron microscope (FESEM) was used at $5 \mathrm{kV}$ accelerating voltage. Samples were placed on aluminum stabs using carbon tape.

2.3.5. Thermogravimetric Analysis. Thermal stability and surface weight loss of CAgNPs were analyzed by SDT Q600 V20.9 Build 20, Universal V4.7A TA Instruments, under a nitrogen gas flow of $100.0 \mathrm{~mL} \mathrm{~min}^{-1}$ and heating rate of $10^{\circ} \mathrm{C} \mathrm{min}^{-1}$ to $1000^{\circ} \mathrm{C}$.

2.3.6. Mosquito Larvicidal Bioassay. One gram of aqueous leaf extract was first dissolved in $100 \mathrm{~mL}$ of DDW (stock solution). From the stock solution, a $100 \mathrm{mg} \mathrm{L}^{-1}$ solution was prepared with dechlorinated tap water for the bioassay. The larvicidal activity was assessed by the procedure of WHO [47] with some modifications [48]. Toxicity testing was performed by placing 20 late third- and fourth-instar larvae mosquito larvae into $200 \mathrm{~mL}$ of sterilized DDW with AgNPs in a $250 \mathrm{~mL}$ beaker (Borosil) at a temperature of $25^{\circ} \mathrm{C}$ and $16: 8 \mathrm{~h}$ light/dark cycle. Approximately $100 \mathrm{mg}$ of synthesized AgNPs was dissolved in $1 \mathrm{~L}$ of Milli-Q water (stock solution). From the stock solution, the nanoparticle solutions were diluted using Milli-Q water as a solvent according to the desired concentrations $\left(10,7.5,5\right.$, and $\left.2.5 \mathrm{mg} \mathrm{L}^{-1}\right)$. Each test included a control group (silver nitrate and distilled water) with five replicates for each individual concentration. Mortality was assessed after $24 \mathrm{~h}$ and $48 \mathrm{~h}$ to determine the acute toxicities. To avoid settling of particles especially at higher doses, all

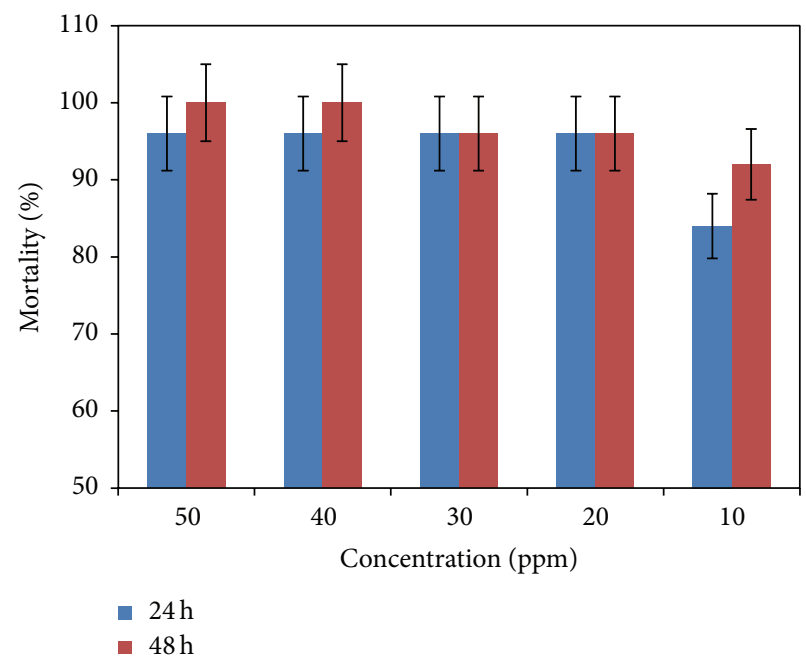

FIGURE 1: Dose response of CAgNPs against the exposed late thirdand fourth-instar larva of Culex quinquefasciatus.

treatment solutions were sonicated for an additional $5 \mathrm{~min}$ prior to addition of the mosquito larvae.

2.3.7. Dose Response Bioassay. Different concentrations (50, $40,30,20$, and $10 \mathrm{mg} \mathrm{L}^{-1}$ ) of CAgNPs were evaluated for the bioassay. The numbers of dead larvae were counted after $24 \mathrm{~h}$ and $48 \mathrm{~h}$ of exposure, and the percent mortality was reported from the average of five replicates.

Control mortality was corrected by using Abbott's formula, and percentage mortality is calculated as follows:

$$
\begin{aligned}
\text { Percentage Mortality }= & \frac{\text { Number of Dead Larvae }}{\text { Number of larvae introduced }} \\
& \times 100 .
\end{aligned}
$$

2.4. Data Analysis. The average larval mortality data were subjected to probit analysis for calculating $\mathrm{LC}_{50}, \mathrm{LC}_{90}$, and other statistics at $95 \%$ fiducial limits of upper confidence limit and lower confidence limit, and chi-square values were calculated using BioStat computer software programs version 3.2. Results with $p<0.05$ were considered to be statistically significant.

\section{Results and Discussion}

3.1. Larvicidal Activity of CAgNPs. CAgNPs showed $>95 \%$ cidal activity against all the exposed late third- and fourthinstar larva of Culex quinquefasciatus within $48 \mathrm{~h}$ at concentrations higher than $10 \mathrm{ppm}$ (Figure 1). At 20 and $30 \mathrm{ppm}$ of CAgNPs, the percentage mortality was recorded as 96 for $24 \mathrm{~h}$ and $48 \mathrm{~h}$. This showed that $4 \%$ of the larvae were still active. The percentage mortality recorded for 40 and $50 \mathrm{ppm}$ was 100 at $48 \mathrm{~h}$. This showed complete death of all the test larvae. These results suggest that the rate of the CAgNPs entry into the larvae body is not the same and the dose response bioassay showed that concentrations less than $10 \mathrm{ppm}$ are suitable for larvicidal studies. 
TABLE 1: Larvicidal activity of CAgNPs against different instar of C. quinquefasciatus.

\begin{tabular}{|c|c|c|c|c|c|c|c|}
\hline \multirow{2}{*}{$\begin{array}{l}\text { Concentration } \\
(\mathrm{ppm})\end{array}$} & \multicolumn{3}{|c|}{ Larva instar \% mortality } & \multirow{2}{*}{$\mathrm{LC}_{50}(\mathrm{ppm})(\mathrm{LCL}-\mathrm{UCL})$} & \multirow{2}{*}{$\mathrm{LC}_{90}(\mathrm{ppm})(\mathrm{LCL}-\mathrm{UCL})$} & \multirow{2}{*}{ Slope } & \multirow{2}{*}{$\chi^{2}(\mathrm{df}=3)$} \\
\hline & I & II & III \& IV & & & & \\
\hline Control & & & $0.00 \pm 0.00$ & & & & \\
\hline 2.5 & & & $58.0 \pm 16.43$ & & & & \\
\hline 5.0 & $* *$ & & $76.1 \pm 13.42$ & $4.43(3.65-5.16)$ & $8.37(7.84-8.90)$ & 4.629 & 1.76 \\
\hline 7.5 & & $* *$ & $84.3 \pm 11.40$ & & & & \\
\hline 10.0 & & & $94.5 \pm 8.94$ & & & & \\
\hline
\end{tabular}

** $100 \%$ mortality; $\mathrm{LC}_{50}$ lethal concentration that kills $50 \%$ of the exposed larvae; $\mathrm{LC}_{90}$ lethal concentration that kills $90 \%$ of the exposed larvae; percent cumulative mortality values are mean $\pm \mathrm{SD}$.

The larvae of Culex quinquefasciatus were highly susceptible to CAgNPs. Larvicidal studies were done using concentrations ranging from $2.5 \mathrm{ppm}$ to $10 \mathrm{ppm}$ of CAgNPs (Table 1). Mortality of larvae increased with increasing concentration. The $\mathrm{LC}_{50}$ and $\mathrm{LC}_{90}$ values after $24 \mathrm{~h}$ exposure were $4.43 \mathrm{ppm}$ and $8.37 \mathrm{ppm}$, respectively (Table 1). Phenolic phytochemicals, saponins, flavonoids, and terpenoids which are also present in the $C$. hirsuta leaf extract have been reported to possess various biological activities such as insecticidal, mosquito larvicidal, ovicidal, and cercaricidal activity. We suggest that these compounds could have enhanced the efficacy of CAgNPs in causing mortality at low concentrations [30]. However, the aqueous leaf extract of C. hirsuta did not show any larvicidal effect. No mortality was also observed in any of the controls. The chi-square value $\left(\chi^{2}\right)$ was significant at the $p \leq 0.05$ level. AgNPs synthesized by green methods are environmentally benign. They have been shown to be effective as larvicidal agents, though the exact mechanism by which larva mortality occurs is unknown. It has been suggested that AgNPs easily penetrate into the mosquito larval body and bind to sulfur-containing proteins or to phosphate groups of DNA. This leads to the denaturing of some cell organelles, therefore resulting in decreased membrane permeability with loss of cellular functions and finally cell death [39].

Raman et al. [33] reported on the larvicidal activity of AgNPs biosynthesized using Pithecellobium dulce. These nanoparticles showed effective larvicidal activity against Culex quinquefasciatus $\left(\mathrm{LC}_{50}=21.56 \mathrm{mg} \mathrm{L}^{-1}\right.$ and $r^{2}=0.995$ ) due to high surface-to-volume ratio. Veerakumar et al. [6] synthesized AgNPs from Sida acuta leaves. Mosquito larvicidal activity of synthesized AgNPs against the vector mosquitoes of $A$. stephensi, A. aegypti, and C. quinquefasciatus had the following $\mathrm{LC}_{50}$ and $\mathrm{LC}_{90}$ values: 21.92 and $41.07 \mu \mathrm{g} \mathrm{mL}^{-1} ; 23.96$ and $44.05 \mu \mathrm{g} \mathrm{mL}^{-1} ; 26.13$ and $47.52 \mu \mathrm{g} \mathrm{mL}^{-1}$, respectively. Rawani et al. [37] reported that AgNPs synthesized by aqueous extracts of Solanum nigrum L. showed $\mathrm{LC}_{50}$ values of $1.33,1.59$, and $1.56 \mathrm{ppm}$ and $\mathrm{LC}_{90}$ values of 3.97, 7.31, and $4.76 \mathrm{ppm}$ for dry leaves, fresh leaves, and berries, respectively against Anopheles stephensi. The authors suggested that, after AgNPs reached the larvae midgut epithelial membrane, enzymes were inactivated and generated peroxides lead to cell death.

Rajasekharreddy and Rani [39] synthesized AgNPs using Sterculia foetida L. seed extracts and showed potential mosquito larvicidal activity against Aedes aegypti (L.), Anopheles stephensi Liston, and Culex quinquefasciatus Say. These AgNPs also act as promising agents in cancer therapy. Kumar et al. [28] investigated the larvicidal potential of the Morinda tinctoria and synthesized AgNPs against third-instar larvae of Culex quinquefasciatus Say (Diptera: Culicidae). The value of the AgNPs at 50\% lethal concentration $\left(\mathrm{LC}_{50}\right)$ $=1.442$ ppm against C. quinquefasciatus. Soni and Prakash [27] synthesized AgNPs using aqueous extracts of leaves and bark of $A$. indica (Neem). The synthesized AgNPs were tested as larvicides, pupicides, and adulticides against the malaria vector Anopheles stephensi and filariasis vector Culex quinquefasciatus. The first- and the second-instar larvae of $C$. quinquefasciatus showed a mortality rate of $100 \%$ after $30 \mathrm{~min}$ of exposure. The pupicidal activity against C. quinquefasciatus was recorded as $\mathrm{LC}_{50}$ of $4 \mathrm{ppm}, \mathrm{LC}_{90}$ of $11 \mathrm{ppm}$, and $\mathrm{LC}_{99}$ of $13 \mathrm{ppm}$ after $3 \mathrm{~h}$ of exposure. In the case of adult mosquitoes, $\mathrm{LC}_{50}$ of $1.06 \mu \mathrm{L} \mathrm{cm}{ }^{-2}, \mathrm{LC}_{90}$ of $2.13 \mu \mathrm{L} \mathrm{cm}^{-2}$, and $\mathrm{LC}_{99}$ of $2.4 \mu \mathrm{L} \mathrm{cm}^{-2}$ were obtained after $4 \mathrm{~h}$ of exposure. Vimala et al. [34] synthesized AgNPs using Couroupita guianensis. Extensive mortality rate for leaf synthesized AgNPs was reported with $\mathrm{LC}_{50}$ of $2.1 \mathrm{ppm}$ and $\mathrm{LC}_{90}$ of $5.59 \mathrm{ppm}$ and flower synthesized AgNPs with $\mathrm{LC}_{50}$ of $2.09 \mathrm{ppm}$ and $\mathrm{LC}_{90}$ of $5.7 \mathrm{ppm}$.

3.2. UV-Visible Study. The aqueous leaf extract of C. hirsuta reduced $\mathrm{Ag}^{+}$to $\mathrm{Ag}^{0}$. This was confirmed by the gradual color change of the final mixture from light yellow to yellowish brown (Figure 2(a) inset) indicating the formation of AgNPs [15]. Phytochemicals like tannins, alkaloids, glycosides, and flavonoids in the leaf extract $[43,45]$ are responsible for the reduction and stabilization of $\mathrm{Ag}^{+}$to $\mathrm{Ag}^{0}$ nanoparticles. The surface plasmon resonance (SPR) band was observed at $440 \mathrm{~nm}$ for $30^{\circ} \mathrm{C}$ and $420 \mathrm{~nm}$ for both $50^{\circ} \mathrm{C}$ and $80^{\circ} \mathrm{C}$, respectively. The size, shape, state of aggregation, morphology, composition, and the dielectric medium of the nanoparticles affect the SPR. Absorption of light at wavelength of 400$440 \mathrm{~nm}$ is due to collective oscillation of surface electrons in AgNPs [49].

\subsection{Optimization Studies}

3.3.1. Temperature. The electronic spectra of CAgNPs synthesized at $30^{\circ} \mathrm{C}, 50^{\circ} \mathrm{C}$, and $80^{\circ} \mathrm{C}$, respectively, for different time intervals were shown in Figures 2(a)-2(c). The SPR 


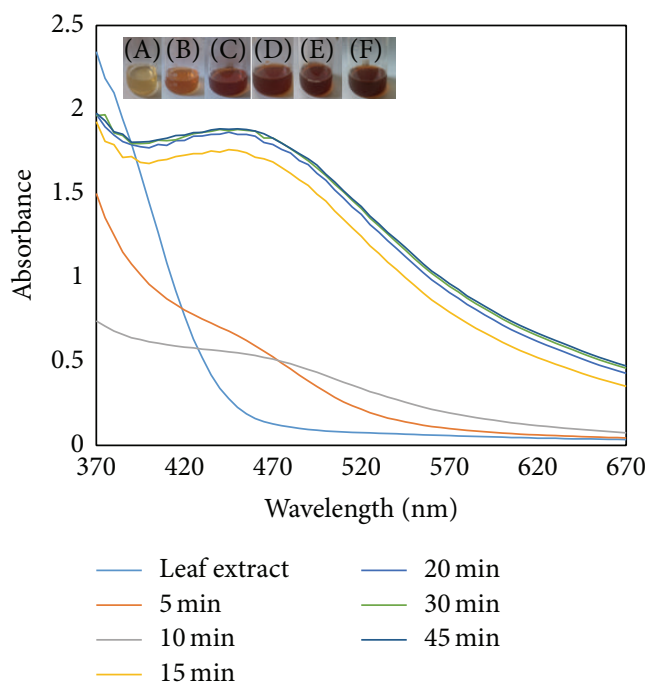

(a)

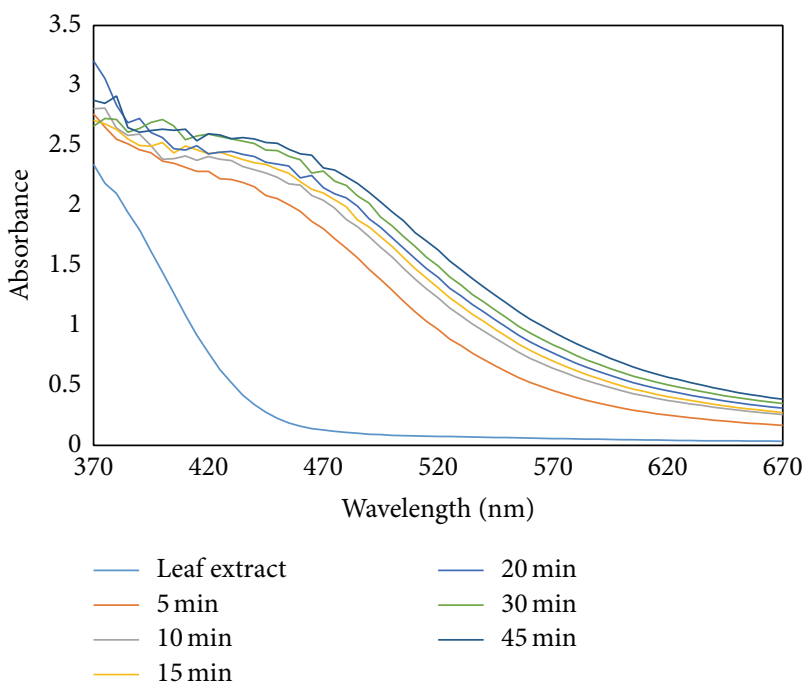

(b)

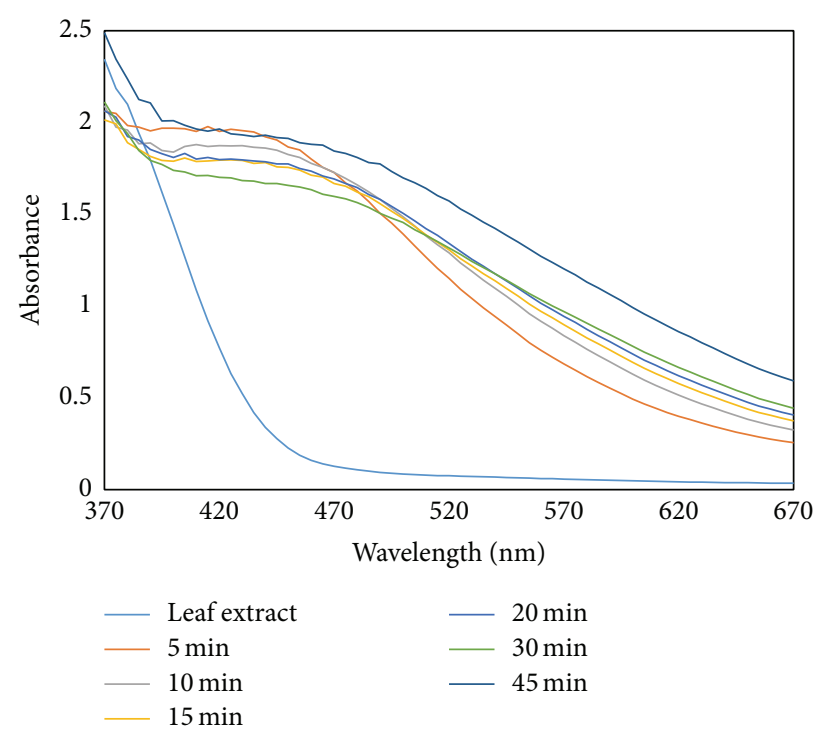

(c)

Figure 2: The UV-visible spectra of CAgNPs synthesized at (a) $30^{\circ} \mathrm{C}$, (b) $50^{\circ} \mathrm{C}$, and (c) $80^{\circ} \mathrm{C}$. Inset: gradual color change at $30^{\circ} \mathrm{C}$ for $(\mathrm{A}) 5 \mathrm{~min}$, (B) $10 \mathrm{~min}$, (C) $15 \mathrm{~min}$, (D) $20 \mathrm{~min}$, (E) $30 \mathrm{~min}$, and (F) $45 \mathrm{~min}$.

observed at 50 and $80^{\circ} \mathrm{C}(420 \mathrm{~nm})$ are at shorter wavelengths, not sharp, and distinct in comparison with the SPR at $30^{\circ} \mathrm{C}(440 \mathrm{~nm})$. This may be due to the decreased size and/or anisotropy degree of the AgNPs [49]. The increase of $20 \mathrm{~nm}$ in the SPR at $30^{\circ} \mathrm{C}$ showed an increase in particle size [50]. For all the temperatures used, an increase in reaction time resulted in an increase in absorbance values. This positive increment in absorption intensity as a function of time signifies enhanced reduction of $\mathrm{Ag}^{+}$to form $\mathrm{Ag}^{0}$ nanoparticles. The SPR band overlapped after $15 \mathrm{~min}$ reaction time for all the temperatures used. This indicates rapid formation of CAgNPs. Therefore, the reaction temperature and time were optimized to $30^{\circ} \mathrm{C}$ and $30 \mathrm{~min}$, respectively.
3.3.2. Volume Ratio. The result of the volume optimization studies ranging $4: 1,3: 2,2: 3$, and $1: 4$ of $1 \mathrm{mM} \mathrm{AgNO}_{3}$ to C. hirsuta aqueous leaf extract, respectively, is presented in Figure 3(a). The SPR at $440 \mathrm{~nm}$ was maintained when one part of the aqueous leaf extract of C. hirsuta was mixed with four parts of $\mathrm{AgNO}_{3}$ solution (1:4). However, a hyperchromic shift was observed when the volume $2: 3$ of $1 \mathrm{mM} \mathrm{AgNO}$ to $C$. hirsuta aqueous leaf extract was reacted for $30 \mathrm{~min}$. The SPR band at $440 \mathrm{~nm}$ disappeared when four parts of aqueous leaf extract of $C$. hirsuta were reacted with one part of $\mathrm{AgNO}_{3}$ solution $(4: 1)$. This suggests that at volume, $4: 1$ of the extract to $\mathrm{AgNO}_{3}$ solution, the reducing and stabilizing agents in the extract could not interact very well with the $\mathrm{Ag}^{+}$ions in the reaction mixture. Therefore, 


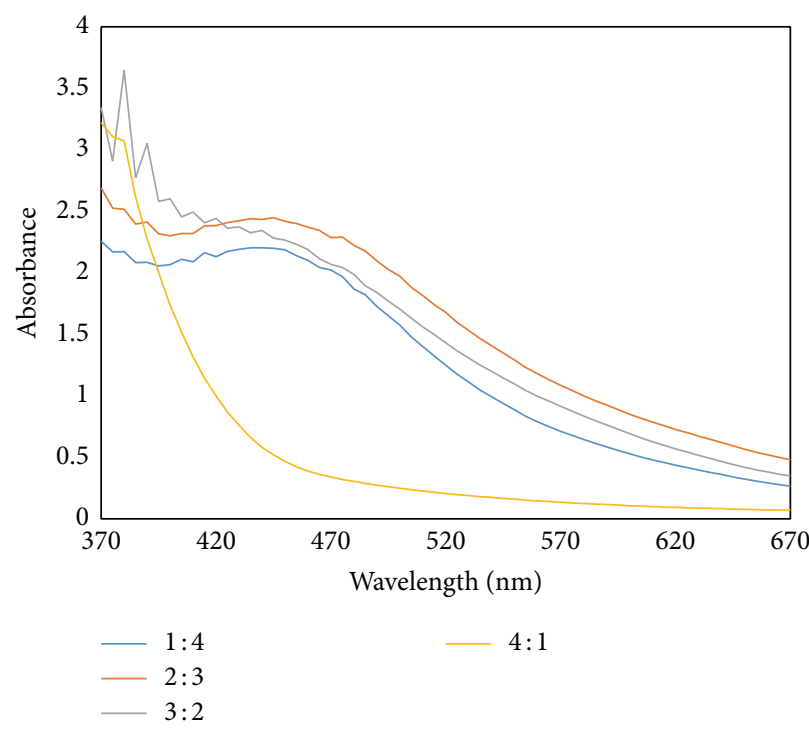

(a)

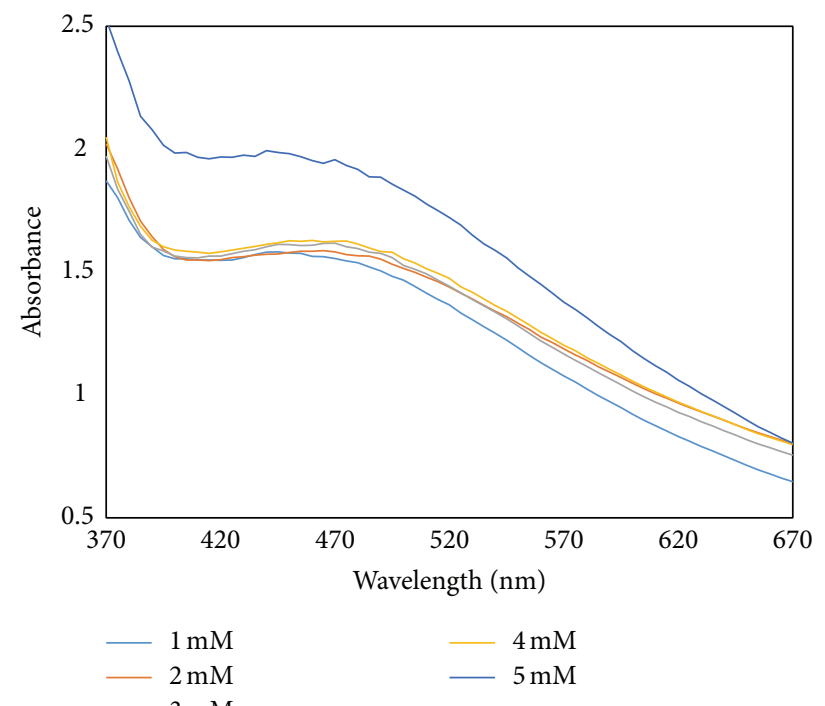

(b)

FIGURE 3: The UV-visible spectra of CAgNPs synthesized at $30^{\circ} \mathrm{C}$ using (a) different volume ratios and (b) varying concentrations.

the optimum reaction volume ratio used throughout this experiment was $1: 4$.

3.3.3. Concentration Variation. The UV-vis absorption spectra of CAgNPs recorded at varying concentrations $(1 \mathrm{mM}-5 \mathrm{mM})$ are presented in Figure 3(a). The reaction was done at optimum reaction conditions $(1: 4$ for $30 \mathrm{~min}$ at $\left.30^{\circ} \mathrm{C}\right)$. The $\mathrm{AgNO}_{3}$ solutions $(1 \mathrm{mM}-4 \mathrm{mM})$ showed the same SPR band and overlapping absorption intensity, while $5 \mathrm{mM}$ exhibited a hyperchromic shift at $440 \mathrm{~nm}$. This suggests that, at higher concentrations of $\mathrm{AgNO}_{3}$, there is also an increase in the number of AgNPs formed [51].

3.4. FTIR Study. Figure 4(a) showed the FTIR spectra of C. hirsuta aqueous leaf extract and CAgNPs, respectively. Sharp $\mathrm{C}=\mathrm{O}$ stretching $\left(1627 \mathrm{~cm}^{-1}\right)$, weak $\mathrm{O}-\mathrm{C}$ stretching $\left(2360 \mathrm{~cm}^{-1}\right)$, and strong, intense $\mathrm{O}-\mathrm{H}$ stretching peaks of alcohols or phenols were observed in the FTIR spectrum of the extract. The appearance of weak band at $2916 \mathrm{~cm}^{-1}$ and $2845 \mathrm{~cm}^{-1}$ in the extract spectrum can be ascribed to the $\mathrm{C}-\mathrm{H}$ stretching of the aliphatic $-\mathrm{CH}_{2}$ moiety. The strong, intense peak at $3455 \mathrm{~cm}^{-1}$ is ascribed to the $\mathrm{O}-\mathrm{H}$ stretch of alcohols or phenols [52]. The absorption bands at $1050 \mathrm{~cm}^{-1}, 1230 \mathrm{~cm}^{-1}$, and $1384 \mathrm{~cm}^{-1}$ can be assigned to the $\mathrm{C}-\mathrm{O}$ stretching vibrations in alcohols, phenols, ethers, esters, and carboxylic acids [53]. These are functional groups that are present in the extract [42-44]. The band at $2916 \mathrm{~cm}^{-1}$ and $2845 \mathrm{~cm}^{-1}$ disappeared in the FTIR spectrum of CAgNPs. The absorption peak at $3455 \mathrm{~cm}^{-1}$ in the extract became sharp and was shifted to $3464 \mathrm{~cm}^{-1}$. Also $\mathrm{C}=\mathrm{O}$ stretching at $1627 \mathrm{~cm}^{-1}$ in the extract was shifted to $1637 \mathrm{~cm}^{-1}$ in the spectrum of CAgNPs. It can be deduced from these that the carbonyl and hydroxyl groups present in tannins, flavonoids, alkaloids, steroids, and glycosides are the main groups responsible for reducing $\mathrm{Ag}^{+}$to $\mathrm{Ag}^{0}$ and capping the CAgNPs.

3.5. Elemental Composition and Morphological Studies. The SEM image (Figure 4(b)) shows that the CAgNPs are small, of varying sizes and aggregates. The purity and elemental composition of CAgNPs were observed by energy dispersive $X$-ray spectroscopy (EDX). The EDX of CAgNPs (Figure 4(c)) shows that $\mathrm{Ag}$ makes up $81 \%$ of the sample, followed by $\mathrm{Cl}(11.46 \%), \mathrm{C}(6.29 \%)$, and lastly O (1.26\%), which may originate from the biomolecules attached to the surface of CAgNPs. The highest count at $3 \mathrm{keV}$ is characteristic of AgNPs. This shows that the synthesis procedure is efficient in producing AgNPs using C. hirsuta leaf. The inset of Figure 4(c) shows the percentage weight of the elements in AgNPs.

The TEM analysis showed that CAgNPs formed at optimum reaction conditions were of spherical morphology, with few larger anisotropic nanoparticles being observed (Figures 5(a) and 5(b)). The particle size ranged from 4.1 to $11.9 \mathrm{~nm}$. The particle size distribution as shown in the plot gave the average size as $6.9 \pm 0.1 \mathrm{~nm}$ (Figure 5(c)). Selected Area Electron Diffraction (SAED) showed that CAgNPs were crystalline with the spots arising from Bragg reflection (Figure 5(d)).

3.6. XRD Analysis. The crystallinity of CAgNPs was confirmed by X-ray diffraction (XRD) patterns. The spectrum showed that diffraction peaks at $38.5^{\circ}, 44.5^{\circ}, 65^{\circ}, 77.8^{\circ}$, and $82^{\circ}$ are indexed to $\left(\begin{array}{lll}1 & 1 & 1\end{array}\right),\left(\begin{array}{lll}2 & 0 & 0\end{array}\right),\left(\begin{array}{lll}2 & 1 & 1\end{array}\right),\left(\begin{array}{lll}2 & 2 & 0\end{array}\right)$, and (llll $\left.\begin{array}{lll}2 & 2\end{array}\right)$ planes of a face center cubic (fcc) lattice of silver crystal. The diffraction peaks were matched with the data of JCPDS number 01-087-0717 [54]. The peak 111 was observed 


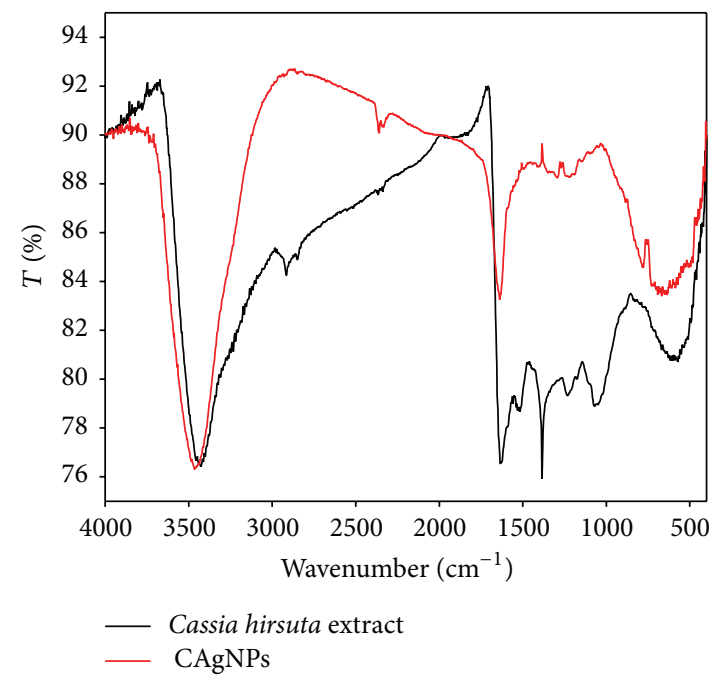

(a)

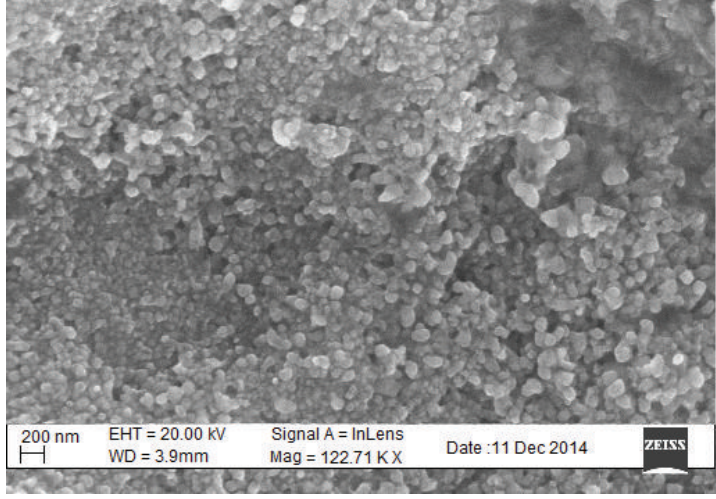

(b)

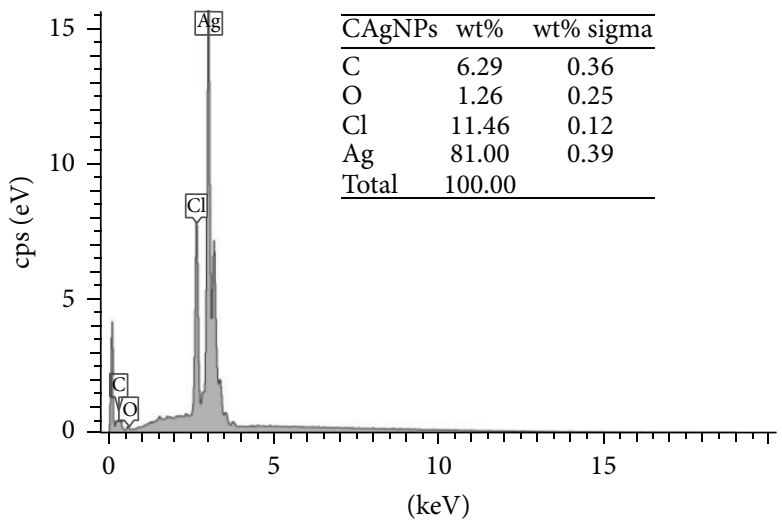

(c)

FIgURE 4: (a) FTIR spectra of extract and CAgNPs (b) SEM images of CAgNPs (c) EDX spectra of CAgNPs. Inset: percentage weight of the elements in CAgNPs.

as the major orientation (Figure 6). This is similar to reports from other researchers $[55,56]$. Other peaks $(*)$ suggest the crystallization of bioorganic phases in the plant extract [5759].

3.7. Thermogravimetric Analysis. Figure 7 showed the DSCTGA of CAgNPs synthesized at the optimum reaction conditions. The percentage weight loss was shown from $30^{\circ} \mathrm{C}$ to $1000^{\circ} \mathrm{C}$. The initial weight loss of about $2 \%$ at the temperature of $70^{\circ} \mathrm{C}$ was due to loss of water molecules from CAgNPs. The weight loss as shown by the TGA graph proceeded in two steps. The first occurred between 70 and $175^{\circ} \mathrm{C}$, while further degradation (about 18\%) was observed between 170 and $400^{\circ} \mathrm{C}$. The degradation which commenced at $170^{\circ} \mathrm{C}$ was suggested to be the decomposition of the bioorganic moiety from CAgNPs. Thermal degradation of CAgNPs was not observed from $400^{\circ} \mathrm{C}$ to $1000^{\circ} \mathrm{C}$. This showed the stability of metallic silver. Also the analysis of DSC curve showed an endothermic peak at $65^{\circ} \mathrm{C}$. This matches with the denaturation enthalpy of CAgNPs at $70^{\circ} \mathrm{C}$ observed in TGA curve. This trend was also reported by Mata et al. [60].

\section{Conclusion}

Successful synthesis of AgNPs using aqueous extracts of $C$. hirsuta leaves has been carried out and its larvicidal potentials are studied. Crystalline spherical CAgNPs of size $6.9 \pm 0.1 \mathrm{~nm}$ were reduced and stabilized by the phytochemical constituents in the extract. Carbonyl and hydroxyl groups were identified by FTIR to participate in the synthesis of AgNPs. CAgNPs showed good mosquito larvicidal potential against Culex quinquefasciatus. The AgNPs were also synthesized at different temperatures. The low cost, energy saving, easy scale-up, and environmental benign method of synthesis was further ascertained by successful synthesis at $30^{\circ} \mathrm{C}$. Therefore, 


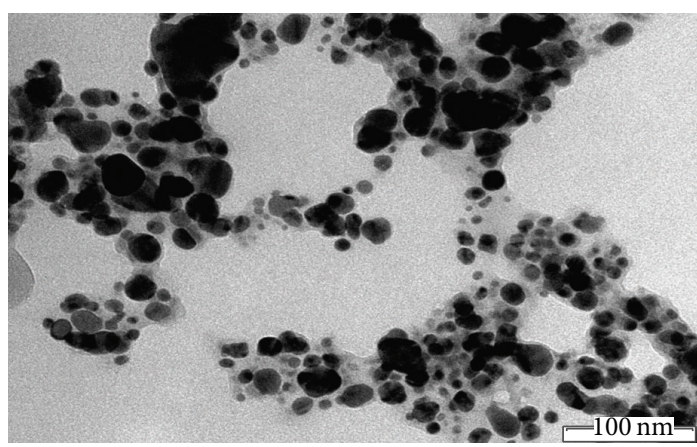

(a)

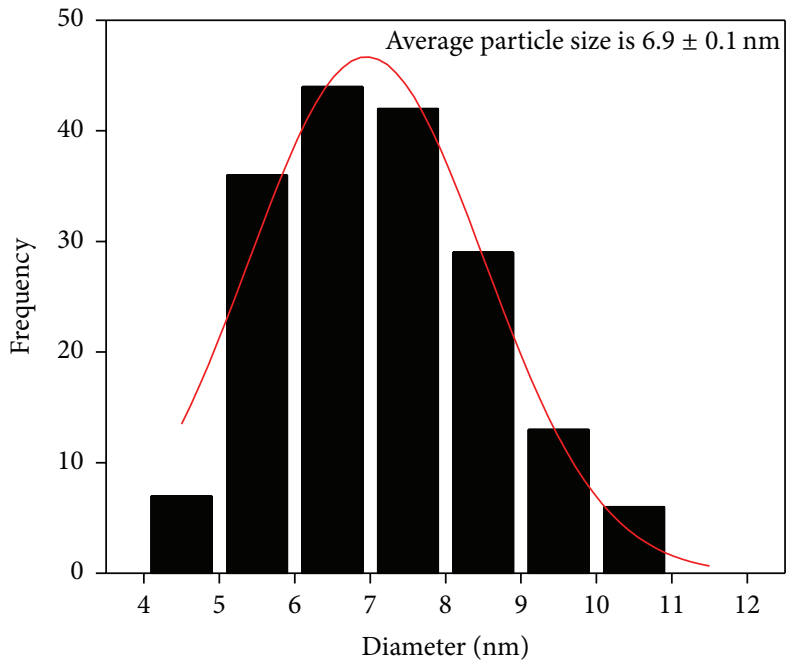

(c)

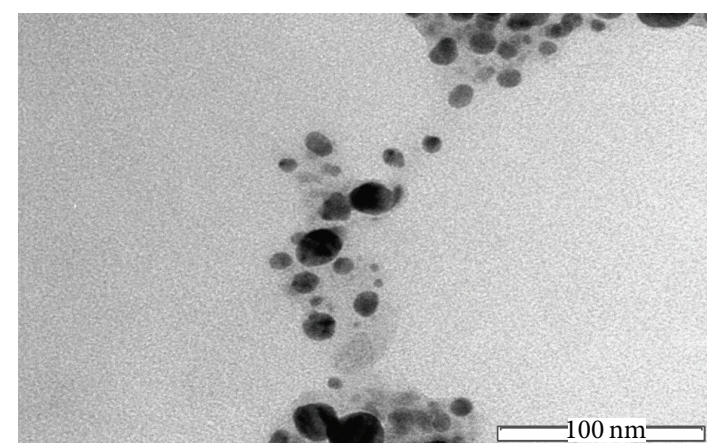

(b)

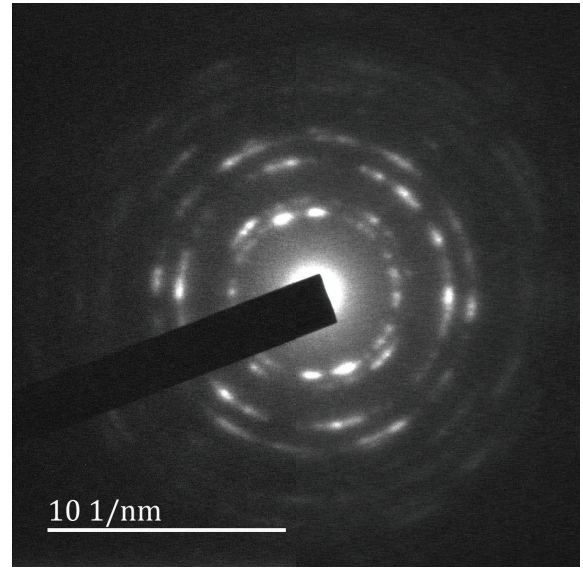

(d)

FIgURE 5: TEM images of CAgNPs at (a) $\times 250 \mathrm{~K} \mathrm{M}$, (b) $\times 400 \mathrm{KM}$, (c) particle size distribution, and (d) SAED pattern of CAgNPs.

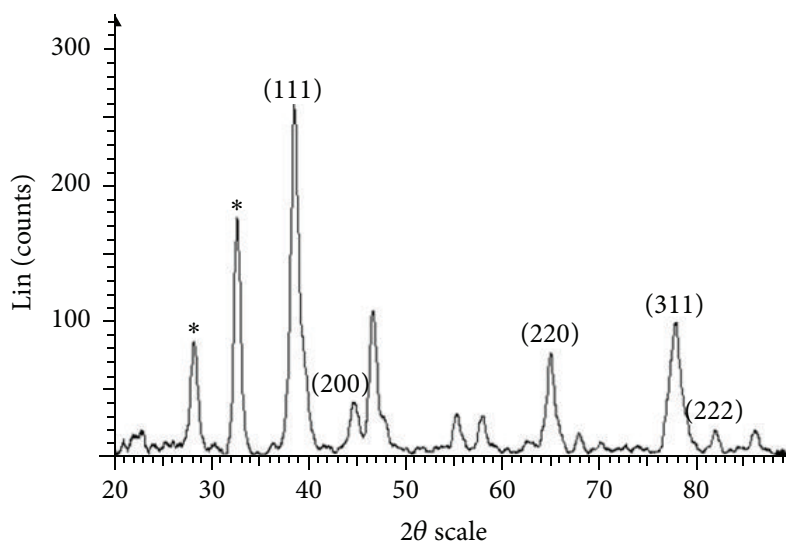

FIgURE 6: XRD spectrum of CAgNPs.

CAgNPs are promising candidates in controlling the menace of mosquitoes in our environment.

\section{Competing Interests}

The authors declare that they have no competing interests.

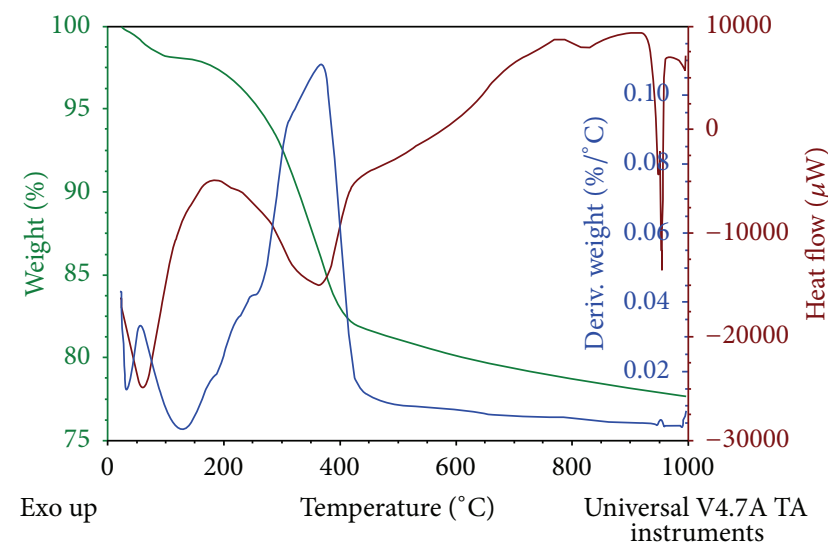

FIgURE 7: DSC-TGA graph of CAgNPs.

\section{Acknowledgments}

The authors wish to acknowledge the Vice Chancellor of Federal University Lafia, Professor Ekanem Ikpi Braide and Dr. A. O. Oduola of the Department of Zoology, University of Ilorin, Ilorin, Nigeria, for their support and help during the course of this research work. 


\section{References}

[1] A. Rawani, A. Ghosh, and G. Chandra, "Mosquito larvicidal activities of Solanum nigrum L. leaf extract against Culex quinquefasciatus Say," Parasitology Research, vol. 107, no. 5, pp. 1235-1240, 2010.

[2] M. B. Ajayi, M. A. Adeleke, E. T. Idowu, and T. S. Awolola, "Surveillance of mosquitoes vectors in Ajumoni Estate Ogun State, Nigeria," Annals of Biological Research, vol. 1, no. 4, pp. $16-19,2010$.

[3] WHO, "Lymphatic filariasis-the disease and its control," Tech. Rep. 71, World Health Organization, Geneva, Switzerland, 2002.

[4] O. J. Afolabi, I. A. Simon-Oke, and B. O. Osomo, "Distribution , abundance and diversity of mosquitoes in Akure, Ondo State, Nigeria," Journal of Parasitology and Vector Biology, vol. 5, no. 10, pp. 132-136, 2013.

[5] WHO, "Lymphatic filariasis, a global brief on vector-borne diseases," WHO/DCO/WHD/2014, vol. 1, pp. 1-56, 2014.

[6] K. Veerakumar, M. Govindarajan, and M. Rajeswary, "Green synthesis of silver nanoparticles using Sida acuta (Malvaceae) leaf extract against Culex quinquefasciatus, Anopheles stephensi, and Aedes aegypti (Diptera: Culicidae)," Parasitology Research, vol. 112, no. 12, pp. 4073-4085, 2013.

[7] P. Maurya, L. Mohan, P. Sharma, L. Batabyal, and C. N. Srivastava, "Larvicidal efficacy of Aloe barbadensis and Cannabis sativa against the malaria vector Anopheles stephensi (Diptera: Culicidae)," Entomological Research, vol. 37, no. 3, pp. 153-156, 2007.

[8] K. Raghavendra and S. K. Subbarao, "Chemical insecticide in malaria vector control in India," ICMR Bulletin, vol. 32, no. 10, pp. 93-99, 2002.

[9] K. Veerakumar and M. Govindarajan, "Adulticidal properties of synthesized silver nanoparticles using leaf extracts of Feronia elephantum (Rutaceae) against filariasis, malaria, and dengue vector mosquitoes," Parasitology Research, vol. 113, no. 11, pp. 4085-4096, 2014.

[10] S. Aboaba, I. Kolade, and O. Olukemi, "Toxicity and mosquito larvicidal activities of the essential oils from the leaves of Acalypha ornata and Acalypha ciliata in southwest Nigeria," Journal of Vector Borne Diseases, vol. 49, pp. 114-116, 2012.

[11] K. M. M. Abou El-Nour, A. Eftaiha, A. Al-Warthan, and R. A. A. Ammar, "Synthesis and applications of silver nanoparticles," Arabian Journal of Chemistry, vol. 3, no. 3, pp. 135-140, 2010.

[12] A. K. Mittal, Y. Chisti, and U. C. Banerjee, "Synthesis of metallic nanoparticles using plant extracts," Biotechnology Advances, vol. 31, no. 2, pp. 346-356, 2013.

[13] S. S. Shankar, A. Rai, A. Ahmad, and M. Sastry, "Rapid synthesis of $\mathrm{Au}, \mathrm{Ag}$, and bimetallic Au core-Ag shell nanoparticles using Neem (Azadirachta indica) leaf broth," Journal of Colloid and Interface Science, vol. 275, no. 2, pp. 496-502, 2004.

[14] B. Mohapatra, R. Kaintura, J. Singh, S. Kuriakose, and S. Mohapatra, "Biosynthesis of high concentration, stable aqueous dispersions of silver nanoparticles using Citrus limon extract," Advanced Materials Letters, vol. 6, no. 3, pp. 228-234, 2015.

[15] E. E. Elemike, C. O. Oseghale, A. Chuku et al., "Evaluation of antibacterial activities of silver nanoparticles green-synthesized using pineapple leaf (Ananas comosus)," Micron, vol. 57, pp. 1-5, 2014.

[16] O. O. Oluwaniyi, H. I. Adegoke, E. T. Adesuji et al., "Biosynthesis of silver nanoparticles using aqueous leaf extract of Thevetia peruviana Juss and its antimicrobial activities," Applied Nanoscience, 2015.
[17] T. C. Prathna, N. Chandrasekaran, A. M. Raichur, and A. Mukherjee, "Biomimetic synthesis of silver nanoparticles by Citrus limon (lemon) aqueous extract and theoretical prediction of particle size," Colloids and Surfaces B: Biointerfaces, vol. 82, no. 1, pp. 152-159, 2011.

[18] B. Mohapatra, S. Kuriakose, and S. Mohapatra, "Rapid green synthesis of silver nanoparticles and nanorods using Piper nigrum extract," Journal of Alloys and Compounds, vol. 637, pp. 119-126, 2015.

[19] G. Singhal, R. Bhavesh, K. Kasariya, A. R. Sharma, and R. P. Singh, "Biosynthesis of silver nanoparticles using Ocimum sanctum (Tulsi) leaf extract and screening its antimicrobial activity," Journal of Nanoparticle Research, vol. 13, no. 7, pp. 29812988, 2011.

[20] Y. K. Mishra, S. Mohapatra, D. Kabiraj et al., "Synthesis and characterization of Ag nanoparticles in silica matrix by atom beam sputtering," Scripta Materialia, vol. 56, no. 7, pp. 629-632, 2007.

[21] K. Manish and G. B. Reddy, "Stability-inspired entrapment of Ag nanoparticles in $\mathrm{ZrO}_{2}$ thin films," Plasmonics, vol. 11, no. 1, pp. 261-267, 2016.

[22] E. O. Dare, C. O. Oseghale, A. H. Labulo et al., "Green synthesis and growth kinetics of nanosilver under bio-diversified plant extracts influence," Journal of Nanostructure in Chemistry, vol. 5, no. 1, pp. 85-94, 2015.

[23] A. N. Banu and C. Balasubramanian, "Myco-synthesis of silver nanoparticles using Beauveria bassiana against dengue vector, Aedes aegypti (Diptera: Culicidae)," Parasitology Research, vol. 113, no. 8, pp. 2869-2877, 2014.

[24] A. N. Banu and C. Balasubramanian, "Optimization and synthesis of silver nanoparticles using Isaria fumosorosea against human vector mosquitoes," Parasitology Research, vol. 113, no. 10, pp. 3843-3851, 2014.

[25] G. Suganya, S. Karthi, and M. S. Shivakumar, "Larvicidal potential of silver nanoparticles synthesized from Leucas aspera leaf extracts against dengue vector Aedes aegypti," Parasitology Research, vol. 113, no. 3, pp. 875-880, 2014.

[26] K. Veerakumar, M. Govindarajan, M. Rajeswary, and U. Muthukumaran, "Low-cost and eco-friendly green synthesis of silver nanoparticles using Feronia elephantum (Rutaceae) against Culex quinquefasciatus, Anopheles stephensi, and Aedes aegypti (Diptera: Culicidae)," Parasitology Research, vol. 113, no. 5, pp. 1775-1785, 2014.

[27] N. Soni and S. Prakash, "Silver nanoparticles: a possibility for malarial and filarial vector control technology," Parasitology Research, vol. 113, no. 11, pp. 4015-4022, 2014.

[28] K. R. Kumar, N. Nattuthurai, P. Gopinath, and T. Mariappan, "Synthesis of eco-friendly silver nanoparticles from Morinda tinctoria leaf extract and its larvicidal activity against Culex quinquefasciatus," Parasitology Research, vol. 114, no. 2, pp. 411417, 2014.

[29] F. C. Nunes, J. A. Leite, L. H. G. Oliveira et al., "The larvicidal activity of Agave sisalana against L4 larvae of Aedes aegypti is mediated by internal necrosis and inhibition of nitric oxide production," Parasitology Research, vol. 114, no. 2, pp. 543-549, 2015.

[30] G. Rajakumar and A. Abdul Rahuman, "Larvicidal activity of synthesized silver nanoparticles using Eclipta prostrata leaf extract against filariasis and malaria vectors," Acta Tropica, vol. 118, no. 3, pp. 196-203, 2011.

[31] K. Velayutham, A. A. Rahuman, G. Rajakumar et al., "Larvicidal activity of green synthesized silver nanoparticles using bark 
aqueous extract of Ficus racemosa against Culex quinquefasciatus and Culex gelidus," Asian Pacific Journal of Tropical Medicine, vol. 6, no. 2, pp. 95-101, 2013.

[32] N. K. Mondal, A. Chowdhury, U. Dey et al., "Green synthesis of silver nanoparticles and its application for mosquito control," Asian Pacific Journal of Tropical Disease, vol. 4, no. 1, pp. S204S210, 2014.

[33] N. Raman, S. Sudharsan, V. Veerakumar, N. Pravin, and K. Vithiya, "Pithecellobium dulce mediated extra-cellular green synthesis of larvicidal silver nanoparticles," Spectrochimica Acta Part A: Molecular and Biomolecular Spectroscopy, vol. 96, pp. 1031-1037, 2012.

[34] R. T. V. Vimala, G. Sathishkumar, and S. Sivaramakrishnan, "Optimization of reaction conditions to fabricate nanosilver using Couroupita guianensis Aubl. (leaf \& fruit) and its enhanced larvicidal effect," Spectrochimica Acta Part A: Molecular and Biomolecular Spectroscopy, vol. 135, pp. 110-115, 2015.

[35] G. Suresh, P. H. Gunasekar, D. Kokila et al., "Green synthesis of silver nanoparticles using Delphinium denudatum root extract exhibits antibacterial and mosquito larvicidal activities," Spectrochimica Acta Part A: Molecular and Biomolecular Spectroscopy, vol. 127, pp. 61-66, 2014.

[36] D. Dhanasekaran and R. Thangaraj, "Evaluation of larvicidal activity of biogenic nanoparticles against filariasis causing Culex mosquito vector," Asian Pacific Journal of Tropical Disease, vol. 3, no. 3, pp. 174-179, 2013.

[37] A. Rawani, A. Ghosh, and G. Chandra, "Mosquito larvicidal and antimicrobial activity of synthesized nano-crystalline silver particles using leaves and green berry extract of Solanum nigrum L. (Solanaceae: Solanales)," Acta Tropica, vol. 128, no. 3, pp. 613-622, 2013.

[38] S. M. Roopan, Rohit, G. Madhumitha et al., "Low-cost and eco-friendly phyto-synthesis of silver nanoparticles using Cocos nucifera coir extract and its larvicidal activity," Industrial Crops and Products, vol. 43, no. 1, pp. 631-635, 2013.

[39] P. Rajasekharreddy and P. U. Rani, "Biofabrication of Ag nanoparticles using Sterculia foetida L. seed extract and their toxic potential against mosquito vectors and HeLa cancer cells," Materials Science and Engineering C, vol. 39, no. 1, pp. 203-212, 2014.

[40] R. G. Ayo, "Phytochemical constituents and bioactivities of the extracts of Cassia nigricans Vahl: a review," Journal of Medicinal Plants Research, vol. 4, no. 14, pp. 1339-1348, 2010.

[41] U. A. Essiett and I. E. Bassey, "Comparative phytochemical screening and nutritional potentials of the flowers (petals) of Senna alata (1.) roxb, Senna hirsuta (1.) Irwin and barneby, and Senna obtusifolia (1.) Irwin and barneby (fabaceae)," Journal of Applied Pharmaceutical Science, vol. 8, pp. 97-101, 2013.

[42] T. Athiperumalsami, V. Kumar, and L. L. Jesudass, "Survey and phytochemical analysis of seagrasses in the gulf of Mannar, southeast coast of India," Botanica Marina, vol. 51, no. 4, pp. 269-277, 2008.

[43] U. Veerachari and A. K. Bopaiah, "Preliminary phyto-chemical evaluation of the leaf extract of five cassia species," Journal of Chemical and Pharmaceutical Research, vol. 3, no. 5, pp. 574583, 2011.

[44] S. S. N. K. Venkata, Y. N. Lakshmi, and V. V. V. S. Kasapu, "Preliminary phytochemical analysis of some important indian plant species," International Journal of Pharma and Bio Sciences, vol. 1, no. 4, pp. 351-358, 2010.
[45] M. A. Rahman, M. A. Rahman, and N. U. Ahmed, "Phytochemical and biological activities of ethanolic extract of C. hirsuta leaves," Bangladesh Journal of Scientific and Industrial Research, vol. 48, no. 1, pp. 43-50, 2013.

[46] C. Kamaraj, A. Bagavan, A. A. Rahuman, A. A. Zahir, G. Elango, and G. Pandiyan, "Larvicidal potential of medicinal plant extracts against Anopheles subpictus Grassi and Culex tritaeniorhynchus Giles (Diptera: Culicidae)," Parasitology Research, vol. 104, no. 5, pp. 1163-1171, 2009.

[47] World Health Organization, Guidelines for Laboratory and Field Testing of Mosquito Larvicides. Communicable Disease Control, Prevention and Eradication, WHO Pesticide Evaluation Scheme, WHO/CDS/WHOPES/GCDPP/1.3, WHO, Geneva, Switzerland, 2005.

[48] A. A. Rahuman, G. Gopalakrishnan, B. S. Ghouse, S. Arumugam, and B. Himalayan, "Effect of Feronia limonia on mosquito larvae," Fitoterapia, vol. 71, no. 5, pp. 553-555, 2000.

[49] N. Yang and W.-H. Li, "Mango peel extract mediated novel route for synthesis of silver nanoparticles and antibacterial application of silver nanoparticles loaded onto non-woven fabrics," Industrial Crops and Products, vol. 48, pp. 81-88, 2013.

[50] B. A. Makwana, D. J. Vyas, K. D. Bhatt, V. K. Jain, and Y. K. Agrawal, "Highly stable antibacterial silver nanoparticles as selective fluorescent sensor for $\mathrm{Fe}^{3+}$ ions," Spectrochimica Acta Part A: Molecular and Biomolecular Spectroscopy, vol. 134, pp. 73-80, 2015.

[51] C. K. Tagad, S. R. Dugasani, R. Aiyer, S. Park, A. Kulkarni, and S. Sabharwal, "Green synthesis of silver nanoparticles and their application for the development of optical fiber based hydrogen peroxide sensor," Sensors and Actuators B: Chemical, vol. 183, pp. 144-149, 2013.

[52] B. Ajitha, Y. Ashok Kumar Reddy, and P. Sreedhara Reddy, "Green synthesis and characterization of silver nanoparticles using Lantana camara leaf extract," Materials Science and Engineering C, vol. 49, pp. 373-381, 2015.

[53] D. L. Pavia, G. M. Lampman, and G. S. Kriz, Introduction to Spectroscopy, Thomson Learning, Belmont, Calif, USA, 3rd edition, 2001.

[54] P. Velusamy, J. Das, R. Pachaiappan, B. Vaseeharan, and K. Pandian, "Greener approach for synthesis of antibacterial silver nanoparticles using aqueous solution of neem gum (Azadirachta indica L.)," Industrial Crops and Products, vol. 66, no. 1, pp. 103-109, 2015.

[55] M. J. Ahmed, G. Murtaza, A. Mehmood, and T. M. Bhatti, "Green synthesis of silver nanoparticles using leaves extract of Skimmia laureola: characterization and antibacterial activity," Materials Letters, vol. 153, pp. 10-13, 2015.

[56] M. Nasrollahzadeh, M. Sajadi, F. Babaei, and M. Maham, "Euphorbia helioscopia Linn as a green source for synthesis of silver nanoparticles and their optical and catalytic properties," Journal of Colloid and Interface Science, vol. 450, pp. 374-380, 2015.

[57] M. R. Bindhu and M. Umadevi, "Antibacterial and catalytic activities of green synthesized silver nanoparticles," Spectrochimica Acta Part A: Molecular and Biomolecular Spectroscopy, vol. 135, pp. 373-378, 2015.

[58] A. Mishra, N. K. Kaushik, M. Sardar, and D. Sahal, "Evaluation of antiplasmodial activity of green synthesized silver nanoparticles," Colloids and Surfaces B: Biointerfaces, vol. 111, pp. 713-718, 2013. 
[59] K. Nafeesa, A. Razi, and S. Meryam, "Robust and fluorescent silver nanoparticles using Artemisia annua: biosynthesis, characterization and antibacterial activity," Biochemical Engineering Journal, vol. 102, pp. 91-97, 2015.

[60] R. Mata, J. R. Nakkala, and S. R. Sadras, "Catalytic and biological activities of green silver nanoparticles synthesized from Plumeria alba (frangipani) flower extract," Materials Science and Engineering C, vol. 51, pp. 216-225, 2015. 

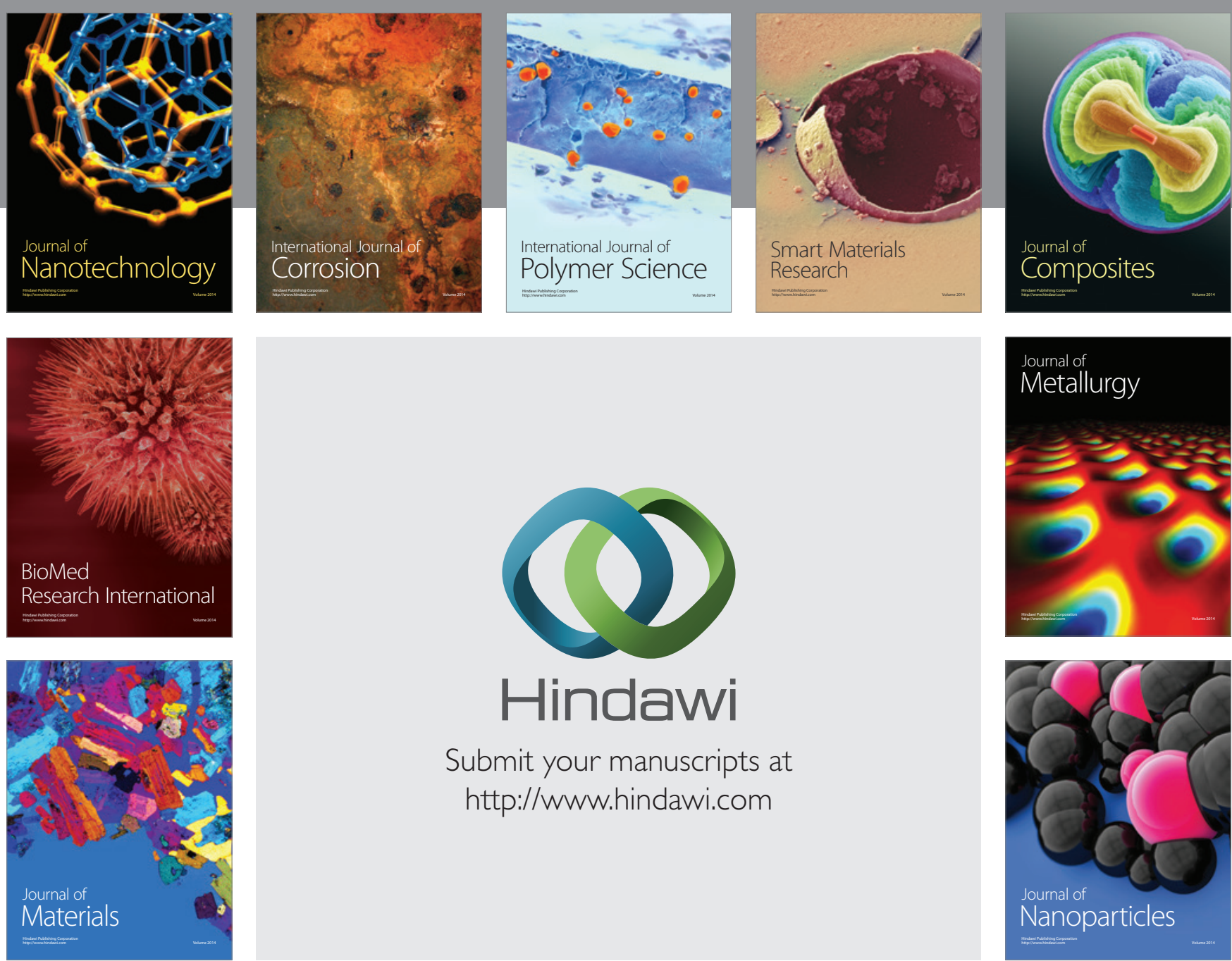

\section{Hindawi}

Submit your manuscripts at

http://www.hindawi.com

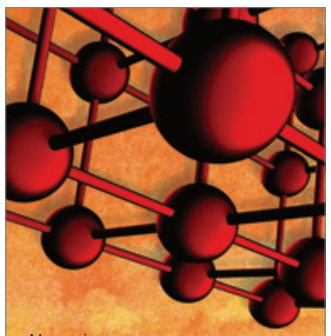

Materials Science and Engineering
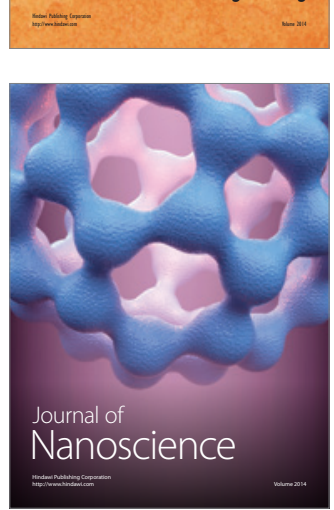
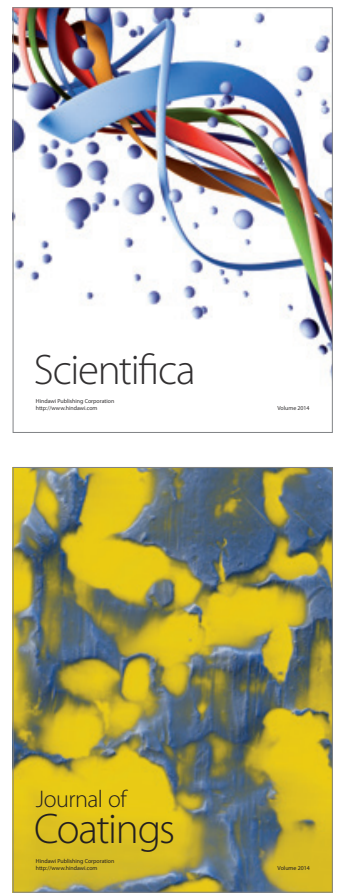
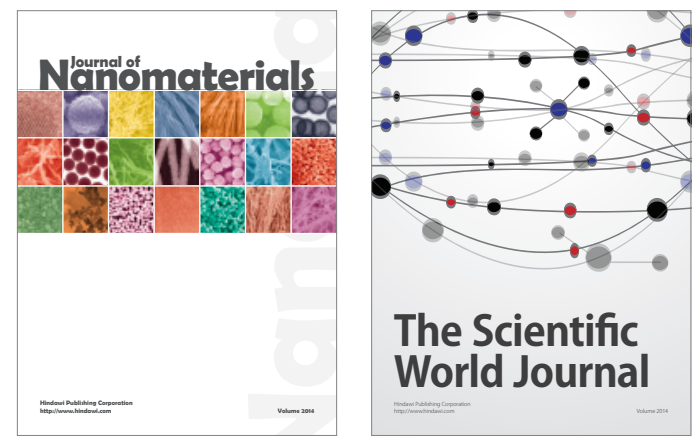

The Scientific World Journal
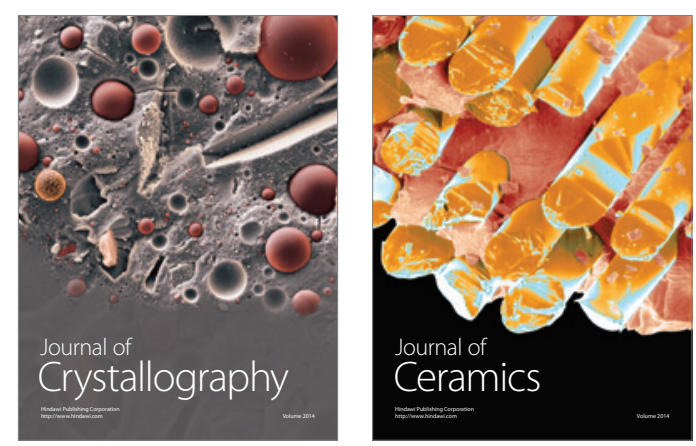
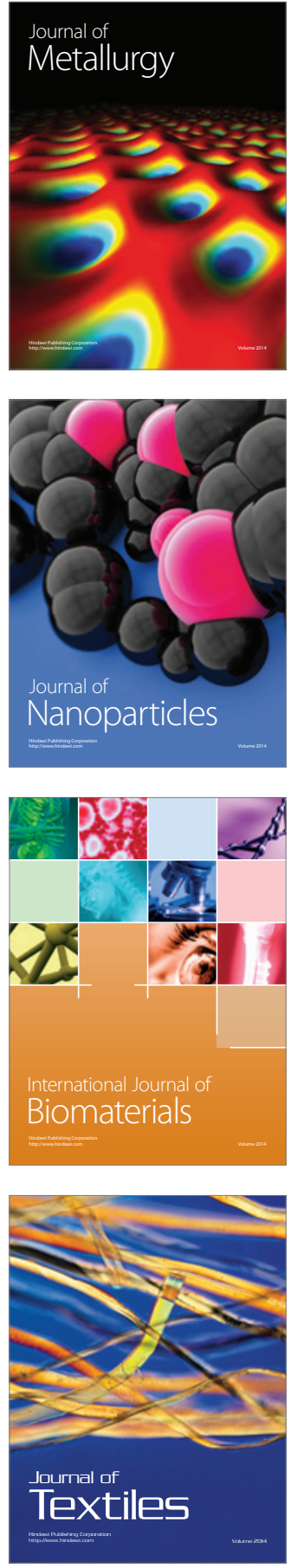